\title{
Brown dog tick Rhipicephalus sanguineus parasitizing the bird Coereba flaveola in the Brazilian cerrado
}

\author{
Carrapato vermelho do cão Rhipicephalus sanguineus parasitando Coereba flaveola \\ no cerrado brasileiro
}

\author{
Matias Pablo Juan Szabó ${ }^{*}$ Graziela Virginia Tolesano Pascoli ${ }^{I I}$ \\ Oswaldo Marçal Júnior ${ }^{\text {II }}$ Alexandre Gabriel Franchin ${ }^{\text {II }}$ Khelma Torga ${ }^{I I}$
}

\section{- NOTE -}

\section{ABSTRACT}

During a survey for ectoparasites on birds in a small reserve of the Brazilian cerrado (savannah) a male adult Rhipicephalus sanguineus tick was found attached to the eyelid of the bird Coereba flaveola. Both tick and bird are presently common in Brazil, however, to best of our knowledge, the association of this tick species with this bird species has not been reported before. This observation may be an accidental finding but might also be an unknown route for the dissemination of the tick. The species $\boldsymbol{R}$. sanguineus was introduced in the country with the colonization and should be considered a research target for the surveillance of tick-borne diseases.

Key words: Rhipicephalus sanguineus, Coereba flaveola, Brazil, Ixodidae, Passeriformes, Cerrado.

\section{RESUMO}

Durante um levantamento sobre ectoparasitos em aves, em uma pequena reserva de cerrado, constatou-se um macho adulto do carrapato Rhipicephalus sanguineus fixado à pálpebra da ave Coereba flaveola. Embora a ave e o parasito sejam abundantes no Brasil, esta associação hospedeiroparasita não foi previamente relatada. Esta observação pode se referir a um fato isolado e acidental, mas também pode se referir a uma via de disseminação antes desconhecida desta espécie de carrapato. A espécie R. sanguineus foi introduzida no Brasil durante a colonização e deve ser considerada um alvo de pesquisas importante na supervisão de doenças transmitidas por carrapatos.

Palavras-chave: Rhipicephalus sanguineus, Coereba flaveola, Brasil, Ixodidae, Passeriformes, Cerrado.
The case herein reported is related to a research on bird ectoparasites conducted at Semideciduous Forest patch (30 hectares), from the Fazenda Experimental do Glória (1856'57"S, 48¹2'14”W), Universidade Federal de Uberlândia (UFU), municipality of Uberlândia, Minas Gerais State, Brazil. Bird capture was performed from March to June 2005 by using mist-nets. Captured birds were identified, weighed, measured and received metallic bands supplied by the Centro Nacional de Pesquisa para Conservação de Aves Silvestres/ Instituto Brasileiro do Meio Ambiente e dos Recursos Renováveis (CEMAVE/IBAMA). All birds were carefully searched for ectoparasites by visual inspection.

On $11^{\text {th }}$ March 2005, a specimen of Coereba flaveola (Linnaeus, 1758) was captured and a small brownish tick was found attached to its eyelid. Based on morphologic features (WALKER et al., 2000; ONOFRIO et al., 2006) this tick was identified as Rhipicephalus sanguineus (Latreille, 1806) and deposited in the Tick Collection of the Universidade Federal de Uberlândia (CC-FAMEV,UFU, accession number 241). No other tick was found on this host. Two other C. flaveola individuals (from a total of eight) were infested with respectively, one and three Amblyomma sp. larvae (CC-FAMEV,UFU, accession numbers 242 and 243).

'Laboratório de Ixodologia da Faculdade de Medicina Veterinária, Universidade Federal de Uberlândia (UFU), Uberlândia, MG, Brasil. Av. Pará, 1720, Campus Umuarama, Bloco 2T, 38400-902, Uberlândia, MG, Brasil. Fone: (034) 3218-2691, fax: (034) 3218-2521. E-mail: szabo@famev.ufu.br. *Autor para correspondência.

"Laboratório de Ornitologia e Bioacústica do Instituto de Biologia, UFU, Uberlândia, MG, Brasil. 
The brown dog tick, $\boldsymbol{R}$. sanguineus, is cosmopolitan and probably the most prevalent of all ixodid species (PEGRAM et al., 1987) and it was introduced in the South American region during colonization (GUGLIELMONE et al., 2006a). In the Neotropical region $\boldsymbol{R}$. sanguineus is an almost exclusive dog tick although it can occasionally be found on other mammals (ARAGÃO, 1936; EVANS et al., 2000; LABRUNA et al., 2005). Its occurrence on wild carnivores, captive or free-living, was always associated to coexistence with domestic dogs (LABRUNA et al., 2005). It is considered the only species of Rhipicephalus in the Neotropical region (GUGLIELMONE et al., 2006a), although the presence of other species of the same genus cannot be ruled out (SZABÓ et al., 2005). Worldwide $\boldsymbol{R}$. sanguineus has been linked to tick-borne diseases such as spotted and boutonneuse fever and ehrlichiosis in humans, and babesiosis and ehrlichioses in dogs (WALKER et al., 2000; DEMMA et al., 2005). Human parasitism has been reported occasionally in the Neotropical region (GUGLIELMONE et al., 2006b).

The Bananaquit, $\boldsymbol{C}$. flaveola is a familiar small bird $(10.5$ to $11 \mathrm{~cm})$ found in South and Central Americas (RIDGELY \& TUDOR, 1989). In Brazil, Bananaquit is considered one of the most abundant birds (SICK, 1997). It lives in open and semiopen habitats, occurring in urban, rural and natural areas (mainly in 'capoeiras' and forest edges). This species is primarily nectarivorous, but also eats fruits and small insects. It is a very active bird and may be seen foraging at different levels of the trees and/or exploring alternative food supplies, as artificial drinking fonts with sugary water (RIDGELY \& TUDOR, 1989; SICK 1997; SIGRIST 2006).

Abundance, behavioral features of both host and parasite described in this report and environmental alterations as well, seem to favor the meeting of $\boldsymbol{C}$. flaveola and $\boldsymbol{R}$. sanguineus. The tick is predominant in urban areas where it may infest as much as 30\% of dogs (SZABÓ et al., 2001); however, heavy infestations occur also in rural areas if dogs are kept under conditions favourable for the tick: inside houses or kennels. At the same time, R. sanguineus tickcontaminated location maintains its infesting capacity for several months thanks to unfed tick longevity, especially that of the adult. Considering that $\boldsymbol{C}$. flaveola has intense activity close to areas with human activities, as well as the longevity and occurrence of $\boldsymbol{R}$. sanguineus on higher places and abundance of both host and tick, meeting of these beings is feasible.

The investigated forest fragment is a small remnant of the Cerrado biome beside the Uberlândia town. The Cerrado is Brazil's tropical savannah, and which is arguably under greater threat than the Amazon rainforest (MARRIS, 2005). Such biome is considered a biodiversity hot spot which means that it is especially rich in endemic species and particularly threatened by human activities (CINCOTTA et al., 2000). The fragment from this report is exposed to the surrounding agricultural activities enhancing the likelihood of entrance of parasites from rural, and from urban areas. The presence of non Neotropical tick species on a bird inside the fragment is an undeniable evidence of such interference.

Parasites of birds are an important research task for the unrestricted movements of their hosts and thus possible bridging among natural, rural and urban areas. As ticks are obligate ectoparasites of mammals, birds, reptiles and amphibians, they are also vectors of a great variety of pathogenic organism groups, including viruses, rickettsiae, bacteria, protozoa and fungi (TELFORD III \& GOETHERT, 2004). In Brazil, the knowledge about ticks on birds is scanty and the role of these hosts in the infectious disease transmission chains is largely unknown. Adult $\boldsymbol{R}$. sanguineus has been previously reported on a pigeon Columba livia (Gmelin, 1789) in Rio de Janeiro (DIOGO et al., 2003). This pigeon species, however, is a non-native bird in Brazil and it is found in high numbers solely inside cities. The Bananaquit, on the other hand, is a Neotropical bird and ubiquitous in nature. Thus, although the parasitism herein reported might merely indicate this bird's coexistence with domestic dogs, it might also be associated with the mixing of tick bornepathogens, ticks and hosts that were held apart by natural barriers and therefore with an unpredicted outcome.

\section{REFERENCES}

ARAGÃO H.B. Ixodidas brasileiros e de alguns paizes limitrophes. Memórias do Instituto Oswaldo Cruz, v.31, n.4, p.759841, 1936.

CINCOTTA R.P. et al. Human populations in the biodiversity hotspots. Nature, v.404, p.990-992, 2000.

DEMMA L.J. et al. Rocky Mountain Spotted Fever from an unexpected tick vector in Arizona. New England Journal of Medicine, v.353, n.6, p.587-594, 2005.

DIOGO, A.A.R. et al. Parasitismo por Rhipicephalus sanguineus Latreille, 1806 em Columba livia Linnaeus na cidade do Rio de Janeiro, Brasil. Entomologia y Vectores, v.10, n.2, p.277280, 2003.

EVANS D.E. et al. A review of the ticks (Acari, Ixodida) of Brazil, their hosts and geographic distribution - 1. The state of 
Rio Grande do Sul, southern Brazil. Memórias do Instituto Oswaldo Cruz, v.95, n.4, p.453-470, 2000.

GUGLIELMONE A.A. et al. Diversidade e importância de carrapatos na sanidade animal. In: BARROS-BATTESTI D.M.B, et al. Carrapatos de importância médico-veterinária da região neotropical: um guia ilustrado para identificação de espécies. São Paulo: Vox/ICTTD-3/Butantan, 2006a. Chap.7, p.115-138.

GUGLIELMONE A.A. et al. Ticks (Ixodidae) on humans in South America. Experimental and Applied Acarology, v.40, p.83-100, 2006b.

LABRUNA M.B. et al. Ticks (Acari: Ixodidae) on wild carnivores in Brazil. Experimental and Applied Acarology, v.36, p.149163, 2005.

MARRIS É. The forgotten ecosystem. Nature, v.437, n.13, p.944-945, 2005.

ONOFRIO, V.C. et al. Família Ixodidae: características gerais, comentários e chaves para gêneros. In: BARROS-BATTESTI D.M.B, et al. Carrapatos de importância médico-veterinária da região neotropical: um guia ilustrado para identificação de espécies. São Paulo: Vox/ICTTD-3/Butantan, 2006. Cap.4, p.29-51.

PEGRAM R.G. et al. Clarification of the Rhipicephalus sanguineus group (Acari, Ixodoidea, Ixodidae). II. R. sanguineus
(Latreille, 1806) and related species. Systematic Parasitology, v.10, p.27-44, 1987.

RIDGELY R.S.; TUDOR G. The birds of South America. Austin: University of Texas, 1989. 516p.

SICK H. Ornitologia brasileira. Rio de Janeiro: Nova Fronteira, 1997. 912p.

SIGRIST T. Aves do Brasil: uma visão artística. 2.ed. São Paulo: Avis Brasilis, 2006. 672p.

SZABÓ M.P.J. et al. Ticks (Acari: Ixodidae) associated with domestic dogs in Franca region, São Paulo, Brazil. Experimental and Applied Acarology, v.25, n.10/11, p.909-916, 2001.

SZABÓ M.P.J. et al. Biological and DNA evidence of two dissimilar populations of the Rhipicephalus sanguineus tick group (Acari: Ixodidae) in South America. Veterinary Parasitology, v.130, p.131-140, 2005.

TELFORD III S.R.; GOETHERT H.K. Emerging tick-borne infections: rediscovered and better characterized, or truly "new”? Parasitology, v.129, p.S301-S327, 2004.

WALKER J.B. et al. The Genus Rhipicephalus (Acari, Ixodidae). A guide to the brown ticks of the world. Cambridge: Cambridge University, 2000. 655p. 